ISSN 0206-5657. Вісник Львівського університету. Серія біологічна. 2018 Випуск 78. С. 70-72 Visnyk of the Lviv University. Series Biology. 2018. Issue 78. P. 70-72

\title{
A MOLECULAR GLANCE ON THE GENUS SAUSSUREA (ASTERACEAE) IN THE EUROPEAN ALPINE SYSTEM: A REPORT ON WORK IN PROGRESS
}

\author{
T. Pochynok
}

\author{
University of Vienna \\ 14, Rennweg St., Vienna 1030, Austria \\ e-mail: tania.pochynok@gmail.com
}

In the European Alpine System sensu Ozenda (1985), i.e. Alps, Carpathians, Pyre-
nees, Apennines, Dinarides, Balkans, four species of Saussurea (Asteraceae) occur: S. al-
pina, S. discolor (= S. lapathifolia), S. porcii, and S. pygmaea. In this talk, preliminary
results on European species of Saussurea sect. Saussurea (Lipschitz 1979), i.e. S. alpina,
S. discolor and S. porcii will be presented. Due to an assumed adaptive radiation of Saus-
surea s. lat. during Miocene, a genus of about 450 species with its greatest diversity in
Siberia, Central Asia, the Himalaya, and the Qinghai-Xizang Plateau, the phylogenetic reso-
lution with classical molecular markers like ITS, trnL-F and psbA-trnH is insufficient for
neither robust phylogeny, nor species delimitation (Wang \& al. 2009). For clarifying the
evolution of European mountain species of Saussurea, the molecular fingerprinting method AFLP was used. The focus was put on S. alpina (Arctic-alpine element, 2x and 4x), S. discolor (European Alpine System, 2x) and the rare and enigmatic Eastern Carpathian endemic S. porcii (Kobiv \& al. 2007, Matis \& al. 2014). Whereas $S$. porcii is clearly separated from the other species what is in line with morphology and its presumed close relationship to the predominantly Siberian S. parviftora $(=S$. serrata), S. alpina and S. discolor reveal more complex evolutionary patterns. Hybridization between S. alpina and S. discolor was so far only speculated (Gremli 1870, Lipschitz 1976). Hybrids could now be proven with AFLPs for the Eastern Alps, where both species occur in parapatry on schists. The clear morphological, ecological and genetic separation of the Western Alpine S. alpina subsp. depressa (2x) from subsp. alpina (2x) could already be shown by Kreuzer \& al. (2014). Recently, S. depressa is even accepted on the species level in Flora Gallica (Tison \& Foucault 2014). According to the AFLP data, populations of S. alpina from the Arctic, the Alps and the Carpathians cluster together. Contrary to Alpine ones, Carpathian populations show higher divergence from each other what is likely due to the fact that the Carpathians where only locally glaciated, not exceeding $1 \%$ of their total area (Ronikier 2011). This could favor rather a Pleistocene migration Altai - Ural - Carpathians - Alps, where the Carpathians acted as a stepping stone, than migration through the Arctic (Gnader-Thimm 1963, Mráz \& Ronikier 2016). The Eastern Alpine-Carpathian S. alpina subsp. macrophylla as accepted in Flora Europaea (Lipschitz 1976) or Flora Alpina (Aeschimann et al. 2004) or other infraspecific taxa of S. alpina reported from the Carpathians (Nyárády 1940, 1964) are not supported by molecular data. The Eastern Carpathian population of S. discolor from Chorny Dil (Ukraine) is clearly separated from those from the Alps. Thus Carpathian S. discolor could represent a unique phylogeographic group, a pattern known from several other high-mountain plants (Ronikier 2011). Within the Alps, the investigated population of S. discolor from Rax (Northeastern calcareous Alps) is more divergent from other from the Alps and shows significantly higher rarity. This corresponds well the other phylogeographic studies on high mountain plants of this refugial area (Schönswetter \& al. 2005, Essl \& Rabitsch 2009). Ongoing research on Saussurea includes the extension of sampling, sequencing of highly variable cpDNA markers from herbarium specimens, population genetics with RAD-Seq, ploidy level estimation with flow cytometry, chromosome counts (the chromosome number for S. porcii is not known!) and morphological analyses. The first genome size measurement for the genus Saussurea could be inferred with Ukrainian material of Saussurea porcii from 
Mt. Hnetiesa: $1 \mathrm{C}=2,60 \mathrm{pg}$, which is higher than in the sister genus Jurinea, J. mollis: $1 \mathrm{C}=$ 1,80 pg (Susanna \& Garcia-Jacas 2009, Siljak-Yakovlev \& al. 2010).

\title{
МОЛЕКУЛЯРНИЙ ОГЛЯД РОДУ SAUSSUREA (ASTERACEAE) У ЄВРОПЕЙСЬКІЙ АЛЬПІЙСЬКІЙ СИСТЕМІ: ЗВIT IЗ НЕЗАВЕРШЕНОЇ РОБОТИ
}

\section{Т. Починок}

\author{
Віденський університет \\ вул. Реннвет, 14, Відень 1030, Австрія \\ e-mail:tania.pochynok@gmail.com
}

\begin{abstract}
У Європейскій альпійській системі за визначенням Ozenda (1985), включаючи Альпи, Карпати, Піренеї, Апенніни, Динарські Альпи, Балкани, трапляються чотири види роду Saussurea (Asteraceae): S. alpina, S. discolor (= S. lapathifolia), S. porcii та S. pygmaea. У доповіді представлено попередні результати по європейських видах роду Saussurea sect. Saussurea (Lipschitz 1979), а саме S. alpina, S. discolor i S. porcii. Відповідно до імовірної адаптивної радіації в міоцені роду Saussurea s. lat., який налічує понад 450 видів із найбільшим різноманіттям у Сибіру, Центральній Азії, Гімалаях та Цинхай-Тибетському плато (Qinghai-Xizang), філогенетична резолюція за допомогою класичних молекулярних маркерів, а саме: ITS, trnL-F, psbA-trnH, недостатня як для достовірної філогенії, так і для розмежування видів (Wang \& al. 2009). Для з'ясування еволюції видів Saussurea у європейських горах було застосовано молекулярний метод фінгерпринту AFLP з фокусом на таких видах, як S. alpina (аркто-альпійський елемент, ди- і тетраплоїд), S. discolor (Свропейска альпійська система, диплоїд) та рідкісний і загадковий східно-карпатський ендемік $S$. porcii (Kobiv \& al. 2007, Matis \& al. 2014). Тим часом, як $S$. porcii чітко відмежований від інших видів, що $є$ у відповідності з його морфологією та імовірним близьким спорідненим зв'язком до переважно сибірського виду $S$. parviflora (= S. serrata), все ж S. alpina i $S$. discolor проявляють більш комплексну еволюційну модель. Про гібридизацію між S. alpina та S. discolor досі лише спекулювали (Gremli 1870, Lipschitz 1976). Але за допомогою AFLP не вдалося підтвердити гібриди для Східних Альп, де обидва види трапляються на сланцях парапатрично. Чітке морфологічне, екологічне та генетичне розмежування S. alpina subsp. depressa (2x) із Західних Альп від subsp. alpina (2x) вдалося показати Kreuzer \& al. (2014). Більше того, нещодавно $S$. depressa прийнято в ранзі виду у Flora Gallica (Tison \& Foucault 2014). Згідно $з$ даними AFLP популяції S. alpina з Арктики, Альп і Карпат згруповані в один кластер. На противагу альпійським карпатські популяції показують вищу дивергентність між собою, що, імовірно, спричинене лише локальним зледенінням у Карпатах, яке не перевищувало 1\% їхньої загальної території (Ronikier 2011). Це могло швидше слугувати для плейстоценової міграції Алтай-Урал-Карпати-Альпи, де Карпати відігравали роль містка (stepping stone), ніж для міграції крізь Арктику (Gnader-Thimm 1963, Mráz \& Ronikier 2016). Східно-альпійсько-карпатський вид $S$. alpina subsp. macrophylla, прийнятий у Flora Europaea (Lipschitz 1976) чи Flora Alpina (Aeschimann et al. 2004), або інші внутрішньовидові таксони S. alpina, наведені з Карпат (Nyárády 1940, 1964), не підтримані молекулярними даними. Популяція S. discolor зі Східних Карпат на Чорному Долі (Україна) чітко відмежована від тих, що в Альпах. Хоча $S$. discolor з Карпат могла би представляти унікальну філогеографічну групу - модель, відома для деяких інших високогірних рослин (Ronikier 2011). В Альпах досліджувана популяція S. discolor із масиву Ракс (північно-східні вапнякові Альпи) $є$ більш дивергентною, порівняно з іншими альпійськими, та має достовірно
\end{abstract}


вищі показники рідкісності. Це узгоджується з філогеографічними дослідженнями інших високогірних рослин цієї території-рефугіуму (Schönswetter \& al. 2005, Essl \& Rabitsch 2009). Дослідження роду Saussurea, яке досі триває, включає розширення вибірки, секвенування високомінливих маркерів пластидної ДНК з гербарних зразків, популяційну генетику з RAD-Seq, визначення рівня плоїдності за допомогою проточної цитометрії, кількості хромосом (число хромосом для $S$. porcii невідоме!) і морфологічний аналіз. Уперше розмір геному для роду Saussurea визначено на основі українських зразків Saussurea porcii з г. Гнєтєса: $1 \mathrm{C}=2,60$ пг, який є вищим, порівняно зі сестринським родом Jurinea, J. mollis: 1C =1,80 пг (Susanna \& Garcia-Jacas 2009, Siljak-Yakovlev \& al. 2010). 